\title{
Assessment of polycyclic aromatic hydrocarbon contamination of the Bílina River (Czech Republic) using passive water samplers and fish biliary metabolites
}

\author{
Jana Blahová1, Lucie Schandlová1, Roman Grabic², Ganna Fedorováe, Tomáš Randák², \\ Zdeňka Svobodová ${ }^{1}$

\begin{abstract}
${ }^{1}$ Department of Veterinary Public Health and Toxicology, Faculty of Veterinary Hygiene and Ecology, University of Veterinary and Pharmaceutical Sciences Brno, Czech Republic and Protection of Waters, Vodňany, Czech Republic
\end{abstract} \\ ${ }^{2}$ South Bohemian Research Center of Aquaculture and Biodiversity of Hydrocenoses, Faculty of Fisheries
}

Received June 27, 2011

Accepted November 15, 2011

\begin{abstract}
The aim of the study was to assess polycyclic aromatic hydrocarbon (PAH) contamination on the Bílina River (the Czech Republic) by measurement of three PAH biliary metabolites in fish and 16 PAHs in passive samplers. A total of sixty-one fish were collected; the indicator species were chub (Leuciscus cephalus L.; $\mathrm{n}=25$ ), roach (Rutilus rutilus $\mathrm{L}$; $\mathrm{n}=17$ ) and brown trout (Salmo trutta $\mathrm{m}$. fario L.; $\mathrm{n}=19$ ). Three biliary PAH metabolites were measured: 1-hydroxypyrene (1-OHP), 2-naphtol, and 1-hydroxyphenanthrene, but only 1-OHP was detected in all fish. The highest median value of $32.3 \mathrm{ng} \cdot \mathrm{mg}^{-1}$ of $1-\mathrm{OHP}$ was found at Ústí nad Labem, while the lowest median value of $27.6 \mathrm{ng} \cdot \mathrm{mg}^{-1}$ was found in the control site, Březenec. No significant differences $(P<0.05)$ among the sites were found. The highest concentration of PAH was detected in Litvínov-Záluží $\left(172.0 \mathrm{ng} \cdot \cdot^{-1}\right)$ and the lowest concentration $\left(7.9 \mathrm{ng} \cdot \mathrm{l}^{-1}\right)$ was detected in Březenec. A positive, but non-significant correlation $\left(r_{s}=0.8\right)$ was confirmed between biliary 1-OHP and total PAH in passive samplers. These results indicate the highest pollution in the middle stretches of the Bílina River, especially at Litvínov-Záluží. We confirmed 1-OHP as the most prevalent PAH biliary metabolite in fish that could be used as a biomarker for assessment of PAH pollution of the aquatic ecosystem. The main importance of the present study is in the combination of biochemical and chemical monitoring that provides complex evaluation of aquatic environment contamination. It was the first study on the Bílina River, in which the assessment of PAH contamination in the aquatic ecosystem was realized using combination of biotic and abiotic monitoring.
\end{abstract}

PAH, 1-hydroxypyrene, SPMD, river pollution, biomonitoring

The environment is continuously loaded by allochtonous organic chemicals that have been produced and, in part, released into the environment by urban communities and industries. The ultimate destination of many of these contaminants is the aquatic environment, either via direct discharge or due to hydrological and atmospheric processes. One group of important ubiquitous environmental contaminants are polycyclic aromatic hydrocarbons (PAH) that are formed mainly by incomplete combustion of organic materials such as fossil fuels, industrial activities, smoked food, and smoked tobacco (Van der Oost et al. 2003).

Many vertebrate aquatic organisms are able to metabolize and excrete PAH rapidly. Since the elimination of PAH is generally efficient in fish, no bioaccumulation of these compounds in fish has been proved. Concentrations of PAH in fish tissue are therefore not indicative of the concentrations to which the animals were exposed and cannot be used as biomarker for exposure assessment (Van der Oost et al. 2003). Fish absorb PAH through the gills and body surface but they can be also exposed through ingestion of food or contaminated sediment (Vuontisjarvi et al. 2004). The liver is the major organ involved in PAH metabolism, and the metabolites produced are secreted into bile and stored in the gall bladder to be excreted. Biliary PAH metabolite analysis provides indirect information regarding the exposure of fish to these contaminants and reveals the state of the

Phone: +420541562785

Fax: +420 541562790

E-mail: blahovaj@vfu.cz

http://www.vfu.cz/acta-vet/actavet.htm 
aquatic environment (Vuontisjarvi et al. 2004). The most common metabolite detected in enzymatically hydrolyzed fish bile is 1-hydroxypyrene (1-OHP) (Ruddock et al. 2003).

The aim of the present study was to assess PAH contamination in 8 selected sites on the Bílina River using fish biliary metabolites. The content of PAH metabolites in fish was compared with PAH content in the passive samplers.

\section{Materials and Methods}

The sites studied on the Bílina River were: Březenec (control site), Jirkov, Jiřetín, Litvínov-Záluží, Želenice, Bílina, Rtyně nad Bílinou, and Ústí nad Labem (Fig. 1). Sixty-one fish were collected from 4 sites on the Bílina River (Březenec, Jirkov, Jiřetín, Ústí nad Labem) in 2010; no fish were caught at the other 4 sites. The indicator species were chub (Leuciscus cephalus L.), roach (Rutilus rutilus L.), and brown trout (Salmo trutta m. fario L.). Fish were weighed and their scales collected for age determination. The main characteristics and number of individual fish species are summarized in Table 1. Bile was drawn by needle through the exposed gall bladder and samples were stored at $-85^{\circ} \mathrm{C}$ for later analysis. Determination of biliary PAH metabolites (1-OHP, 2-naphtol, 1-hydroxyphenanthrene) was conducted by the reverse phase HPLC/FLD method described by Blahova et al. (2008). For data analyses, the metabolite concentrations were normalized to protein content determined using bicinchoninic acid.

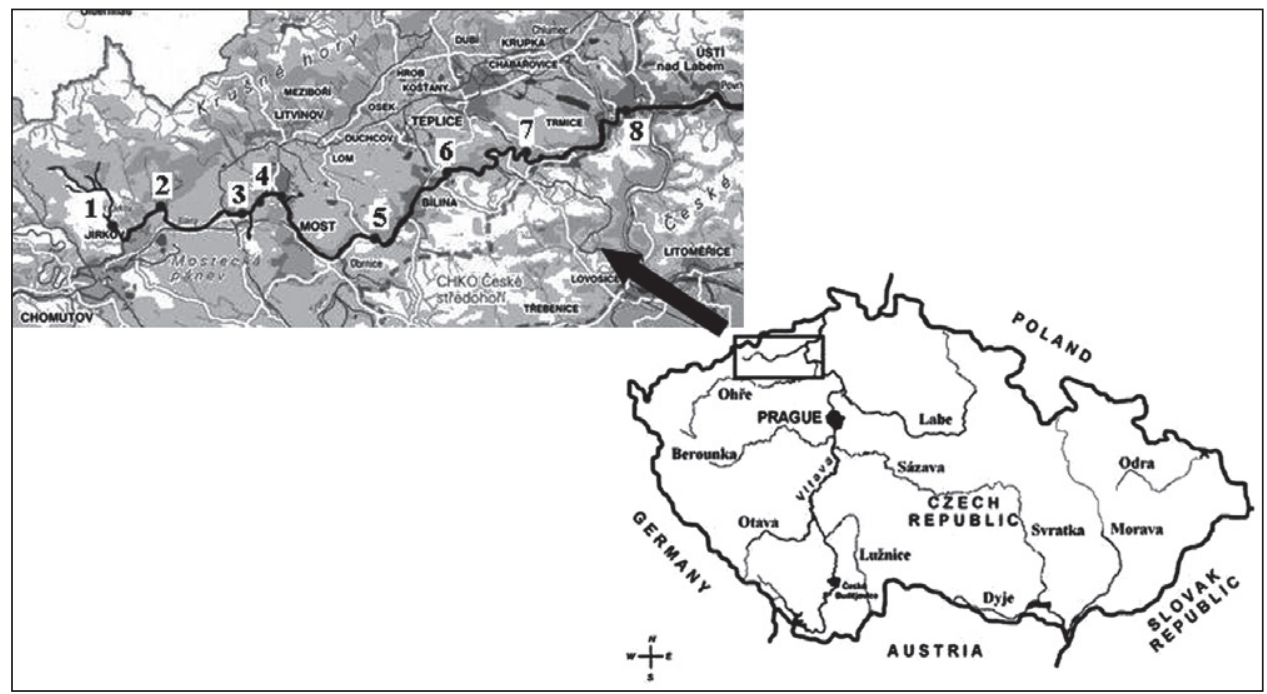

Fig. 1. Study areas on the Bílina River (Czech Republic)

1. Březenec, 2. Jirkov, 3. Jiřetín, 4. Litvínov-Záluží, 5. Želenice, 6. Bílina, 7. Rtyně nad Bílinou, 8. Ústí nad Labem

Table 1. Characteristics of indicator fish from sampling sites

\begin{tabular}{|c|c|c|c|c|}
\hline Indicator fish & Site & $\begin{array}{c}\text { Fish }(\mathrm{n}) \\
\text { (male:female) }\end{array}$ & $\begin{array}{c}\text { Mean age } \\
\text { (min-max) } \\
\text { (years) }\end{array}$ & $\begin{array}{c}\text { Mean weight } \pm \\
\text { SD }(\mathrm{g})\end{array}$ \\
\hline \multirow[t]{3}{*}{ Chub } & Březenec & $8(7: 1)$ & $3.8(3-6)$ & $347.6 \pm 213.8$ \\
\hline & Jirkov & $8(5: 3)$ & $4.1(3-5)$ & $290.4 \pm 106.9$ \\
\hline & Ústí nad Labem & $9(8: 1)$ & $4.3(3-6)$ & $332.1 \pm 168.6$ \\
\hline \multirow[t]{3}{*}{ Roach } & Jirkov & $8(2: 6)$ & $4.4(4-5)$ & $158.6 \pm 59.7$ \\
\hline & Jiřetín & $4(1: 3)$ & $3.0(3-3)$ & $71.8 \pm 8.6$ \\
\hline & Ústí nad Labem & $5(0: 5)$ & $3.6(3-5)$ & $99.0 \pm 44.8$ \\
\hline \multirow[t]{3}{*}{ Trout } & Březenec & $10(3: 7)$ & $2.5(2-3)$ & $81.7 \pm 33.2$ \\
\hline & Jirkov & $8(5: 3)$ & $3.6(2-5)$ & $200.6 \pm 132.5$ \\
\hline & Ústí nad Labem & $1(1: 0)$ & $3.0(3-3)$ & $148.0 \pm 0.0$ \\
\hline
\end{tabular}




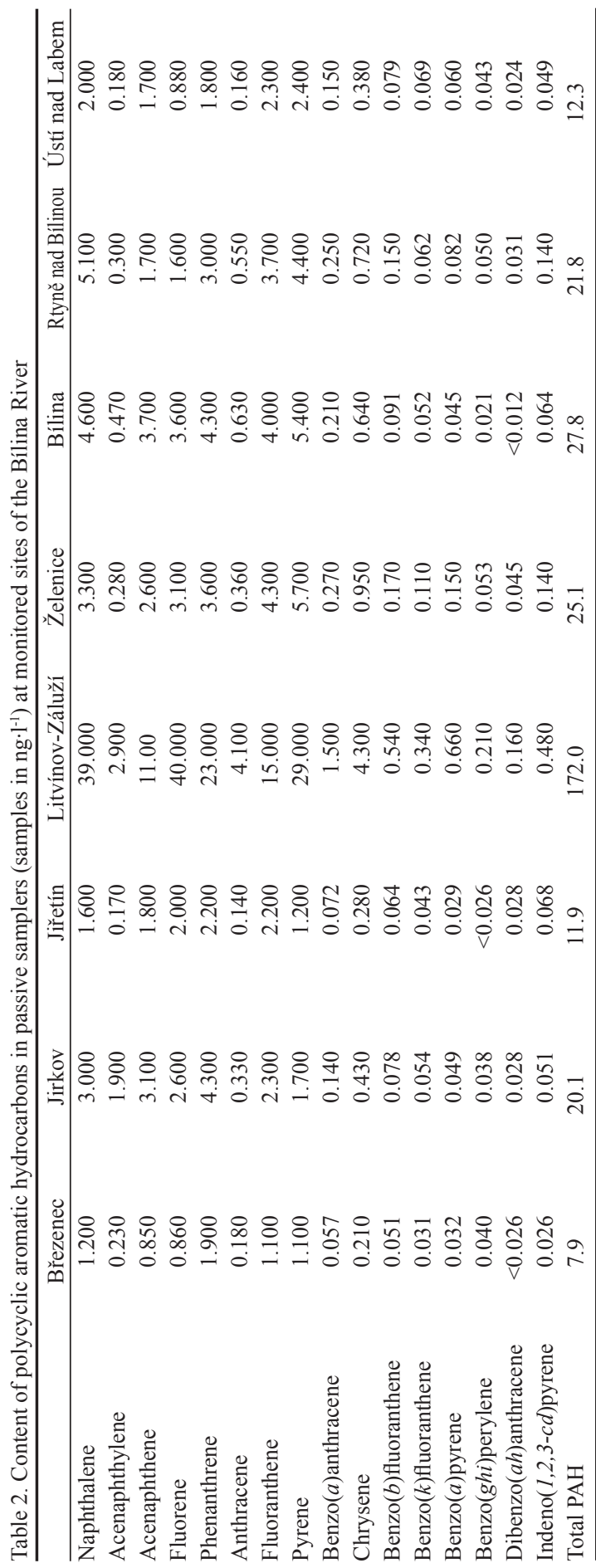

At each site, a single passive sampler (semi-permeable membrane device, SPMD) was installed for 14 days. After exposure, membranes were rinsed briefly with distilled water and placed on ice and transported to the laboratory, where they were stored at -18 ${ }^{\circ} \mathrm{C}$. The analyses for detection of naphthalene, acenaphthylene, acenaphthene, fluorene, phenanthrene, anthracene, fluoranthene, pyrene, benzo $(a)$ anthracene, chrysene, benzo $(b)$ fluoranthene, benzo $(k)$ fluoranthene, benzo(a)pyrene, dibenzo(ah)anthracene, benzo(ghi)perylene and indeno $(1,2,3-c d)$ pyrene were performed after dialyses by gas chromatography combined with high resolution mass spectrometry (Grabic et al. 2010). The United States Environmental Protection Agency (US EPA) has identified these 16 PAHs as particularly important due to their toxicity to mammals and to aquatic organisms.

Statistical analyses were conducted using Statistica 8.0. for Windows software. Individual differences between the means were tested successively using Tukey's-HSD test. The relationship between biliary PAH metabolites and content of PAH in SPMD samples was determined by Spearman's correlation coefficient. For all comparisons, a value of $P<0.05$ was considered significant.

\section{Results}

Three PAH metabolites were measuredinfishbile:1-OHP,2-naphthol, and 1-hydroxyphenanthrene. In all samples, only 1-OHP was quantified, the contents of 2-naphthol and 1-hydroxyphenanthrene were under detection limits. Since there were no significant differences in 1-OHP concentration among fish species within a site, the content of metabolite was compared only among sites. The highest median value of $32.3 \mathrm{ng} \cdot \mathrm{mg}^{-1}$ and the lowest $27.6 \mathrm{ng} \cdot \mathrm{mg}^{-1}$ of 1-OHP were found in fish caught at Ústí nad Labem and at the control site, Březenec, respectively. At the sites Jirkov and Jiřetín, the median values of 1-OHP were 30.78 and $29.41 \mathrm{ng} \cdot \mathrm{mg}^{-1}$, respectively. The differences among sites were not significant.

Passive samplers with SPMD were placed in water at all sites of the Bílina River, and the presence of the 16 US EPA PAHs in water samples 
was determined. The concentrations of individual PAH and sum of PAH are given in Table 2. The total PAH concentrations at all sites ranged from 7.9 to $172.0 \mathrm{ng} \cdot 1^{-1}$. The highest content of PAH was detected at Litvínov-Záluží $\left(172.0 \mathrm{ng} \cdot \mathrm{l}^{-1}\right)$ and the lowest PAH content $\left(7.9 \mathrm{ng} \cdot \mathrm{l}^{-1}\right)$ was detected at the control location, Březenec. The most prevalent PAH at monitored sites were low molecular weight PAH (naphthalene, fluorene, phenanthrene) and pyrene, with levels ranging from 29 to $40 \mathrm{ng} \cdot \mathrm{l}^{-1}$. Correlation analysis confirmed a non-significant positive correlation $\left(\mathrm{r}_{\mathrm{s}}=0.8\right)$ between biliary $1-\mathrm{OHP}$ and sum of PAH in passive samplers.

\section{Discussion}

The Bílina River is considered the most highly polluted river in the Czech Republic. The source of pollution is waste water from industry, municipal sewage, agricultural procedures, and mining activities (Kohusova et al. 2011). The results of a long-term study by Kohusova et al. (2011) indicated that the middle and the lower stretches of the Bílina River were heavily polluted by metals and organic pollutants. The main sources of pollution were oil, coal, the chemical industry, and municipal sewage.

PAHs concentration in water and their fish biliary metabolite differed along the river and reflected the anthropogenic activities in this area. The lowest concentration of PAH pollution was found at the control site, Březenec, which is situated in the upper part of the Bílina River in a relatively unpolluted area. The content of PAH in the passive sampler at this location was less than $5 \%$ of that at the site Litvínov-Záluží, where the highest $\mathrm{PAH}$ content was found. The concentration of 1-OHP was also lowest at this site, but the differences among tested locations were not significant. Slightly higher concentrations of the monitored indices were determined downstream in Jirkov, which is situated at the outlet of waste water treatment plant (WWTP) in the Jirkov town. Comparable concentrations of PAH in water were obtained at all other sites, which are situated at the outlet of WWTPs (Bílina, Rtyně nad Bílinou, downstream from WWTP Teplice). The highest contents of monitored indices were obtained at Litvínov-Záluží, which is influenced by waste waters from Litvínov town and Unipetrol RPA refinery at Litvínov. Similar results were reported by Jurajda et al. (2010), who proved the main anthropogenic pollution of the Bílina River in the Litvínov-Záluží area.

The inferior water quality at the sites located in the middle and the lower stretches of the Bílina River is confirmed by absence of fish in the river. The variability in fish occurrence in the Bílina River was documented by Wenger et al. (2010). The authors assessed the relationships between chemical exposure, parasite infection, fish health, and ecological status of this area. They reported that extremely poor physical river habitat contributed to a sudden decline in macroinvertebrate and fish assemblage quality, which is a well-known phenomenon associated with severe river habitat degradation. Similar results were obtained by Jurajda et al. (2010). They also studied fish and macroinvertebrate communities in the Bílina River ecosystem. The composition of macroinvertebrate assemblages in headwaters and reference sites in the upper Bílina River indicated clean water with a saprobic index of 1.31-1.43 followed by dramatic decline of water quality to a saprobic index of 3.18 in the river downstream of industrial and municipal pollution at Litvínov-Záluží.

In our study, we confirmed the potential of using biliary metabolites for assessment of $\mathrm{PAH}$ contamination in aquatic ecosystems. Other authors have reported that analysis of bile metabolites, especially 1-OHP, is a convenient and relatively rapid method for monitoring PAH contamination in fish (Hosnedl et al. 2003). Ruddock et al. (2003) determined PAH bile metabolite in three fish species from the Severn estuary. They reported that the major metabolite present in all fish was 1-OHP (75-94\% of all metabolites detected). We confirmed that 1-OHP is the main PAH metabolite; this compound was identified in all samples in contrast to other measured metabolites, which were under the limits of detection 
in all samples. We also obtained positive correlations between the amounts of PAH in passive samplers and biliary 1-OHP. Although this correlation was non-significant, the correlation coefficient was relatively high $\left(r_{s}=0.8\right)$. The lack of significance could be the result of low numbers of points in the correlation analysis.

The Bílina River remains an important source of pollution of the Elbe River and consequently of the North Sea. Despite the gradual improvement of the aquatic ecosystems in this area, the water is still highly contaminated and the river communities damaged. The present study indicates that the highest PAH pollution is in the middle stretches of the river's flow, especially at Litvínov-Záluží. This site is affected by waste water from Litvínov town and the refinery, Unipetrol RPA.

\section{Acknowledgements}

This study was supported by the MSM No. 6215712402, IGA 89/2010/FVHE, CENAKVA No. CZ.1.05/2.1.00/01.0024 and the GAJU No. 047/2010/Z.

\section{References}

Blahova J, Kruzikova K, Hilscherova K, Grabic R, Halirova J, Jurcikova J, Ocelka T, Svobodova Z 2008: Biliary 1-hydroxypyrene as a biomarker of exposure to polycyclic aromatic hydrocarbons in fish. Neuroendocrinol Lett 29: 663-668

Grabic R, Jurcikova J, Tomsejova S, Ocelka T, Halirova J, Hypr D, Kodes V 2010: Passive sampling methods for monitoring endocrine disruptors in the Svratka and Svitava rivers in the Czech Republic. Environ Toxicol Contam 29: 550-555

Hosnedl T, Hajšlová J, Kocourek V, Tomaniová M, Volka K 2003: 1-hydroxypyrene as a biomarker for fish exposure to polycyclic aromatic hydrocarbons. Bull Environ Contam Toxicol 71: 465-472

Jurajda P, Adamek Z, Janac M, Valova Z 2010: Longitudinal patterns in fish and macrozoobenthos assemblages reflect degradation of water quality and physical habitat in the Bílina river basin. Czech J Anim Sci 55: 123-136

Kohusova K, Havel L, Vlasak P, Tonika J 2011: A long-term survey of heavy metals and specific organic compounds in biofilms, sediments, and surface water in a heavily affected river in the Czech Republic. Environ Monit Assess 174: 555-572

Ruddock PJ, Bird DJ, McEvoy J, Peters LD 2003: Bile metabolites of polycyclic aromatic hydrocarbons (PAHs) in European eels Anguilla anguilla from United Kingdom estuaries. Sci Total Environ 301: 105-117

Van der Oost R, Beyer J, Vermeulen NPE 2003: Fish bioaccumulation and biomarkers in environmental risk assessment: a review. Environ Toxicol Phar 13: 57-149

Vuontisjarvi H, Keinanen M, Vuorinen PJ, Peltonen K 2004: A comparison of HPLC with fluorescence detection and fixed wavelength fluorescence methods for the determination of polycyclic aromatic hydrocarbon metabolites in fish bile. Polycycl Aromat Comp 24: 333-342

Wenger M, Ondrackova M, Machala M, Neca J, Hyrsl P, Simkova A, Jurajda P, von der Ohe P, Segner H 2010 : Assessing relationships between chemical exposure, parasite infection, fish health and fish exological status: a case study using chub (Leuciscus cephalus) in the Bílina River, Czech Republic. Environ Toxicol Chem 29: $453-466$ 